\title{
Concomitant Septic Arthritis on Gouty Arthropathy: A Case Report
}

\author{
N. E. Lamini N'Soundhat ${ }^{*}$, N. E. Ontsira Ngoyi ${ }^{2}$, D. C. Nkouala Kidede ${ }^{1}$, H. Ntsiba ${ }^{1}$ \\ ${ }^{1}$ Rheumatology Department, Brazzaville University Teaching Hospital, Congo \\ ${ }^{2}$ Bacteriology, Immunology and Virology Laboratory, Brazzaville University Teaching Hospital, Congo \\ Email: "nlamini@yahoo.fr
}

Received 31 March 2016; accepted 28 May 2016; published 31 May 2016

Copyright (C) 2016 by authors and Scientific Research Publishing Inc.

This work is licensed under the Creative Commons Attribution International License (CC BY).

http://creativecommons.org/licenses/by/4.0/

(c) (i) Open Access

\begin{abstract}
We're reporting the case of an arthritis to banal germ occurred in concomitance with an advanced polyarticular of gout. It was about a patient of 59 years with alcoholic and gouty chronicle more than 10 years, but without specialized medical follow-up. He has been admitted in hospitalization for a big inflammatory and stiff right knee, letting rising the pus through two cutaneous fistulas in a context of non-febrile change of his peripheral polyarthritis of the big and small articulations. Gout was at distal predominance, bilateral, distorting, tophaceous and active. Inflammatory syndrome was important (ESR $=50 \mathrm{~mm}$ in the 1 st hour and CRP $=28 \mathrm{mg} / \mathrm{l}$ ) and uricemia was high, at $84 \mathrm{mg} / \mathrm{l}$. The glycaemia, the hepatic, the viral, renal and serological evaluation (HIV and B, C hepatitis) were normal. The bacteriological analysis of the pus collected after puncture of the knee and cleaning identified a negative gram bacillus, Morganella morganii, multi-resistant, but sensitive to the Imipeneme and to the aminosides. The evolution was lethal in a picture of multivisceral failing in spite of a bi-antibiotherapy and under hypo-uricemia treatment prescription.
\end{abstract}

\section{Keywords}

Septic Arthritis, Gout, Brazzaville

\section{Introduction}

Gout is the most frequent inflammatory adult rheumatism in the industrialized countries and in sub-Saharan Africa at the present time [1]. It is a joint inflammation consecutive to the deposit of urate sodium crystals, in relation with a chronic hyperuricemia. The first African works on this topic go back to the years 1990. They contributed to affirm its elevated frequency in black Africa [2]-[4]. The articular infectious complication on

${ }^{*}$ Corresponding author.

How to cite this paper: Lamini N'Soundhat, N.E., Ontsira Ngoyi, N.E., Nkouala Kidede, D.C. and Ntsiba, H. (2016) Concomitant Septic Arthritis on Gouty Arthropathy: A Case Report. Open Journal of Rheumatology and Autoimmune Diseases, 6, 40-44. http://dx.doi.org/10.4236/ojra.2016.62007 
gouty arthropathy seems exceptional and not very described in the literature [5]. We report the case of a septic joint location on a chronic gouty patient in polyarticular outbreak, with the consent of the patient.

\section{Case Report}

It was about a 59 years patient old, alcohol consuming 60 to 80 g per day and gouty known since several years. He has been admitted in the Rheumatology Department of Brazzaville University Teaching Hospital, for a new polyarticular outbreak, interesting the big and small joints. Installation was brutal and spontaneous, evolving since 3 months before. There was no fever, but a deep change of the general state (thinning, asthenia, anorexia). One month before his admission, the right knee itself fistules spontaneously.

At his hospitalization, the patient was conscious, with no fever $\left(37.2^{\circ} \mathrm{C}\right)$. He presented a peripheral joint syndrome, diffuse, bilateral, interesting elbows, wrists, right knee, all metatarso-phalangian joints, the 3rd, 4th, 5th proximal inter-phalangians and the 2nd, 3rd and 5th metacarpo-phalangians of the left hand. The right knee was stiff, hot, and shinier than the other joints. There flowed out some, of spontaneous way, a whitish yellow purulent liquid, through two cutaneous ulcerations of about two centimeters of diameter (Figure 1). The patellar shock was positive. One voluminous tophus in view of the 1st metatarso-phalangian of left foot, right Achille tendon, left knee, back of left wrist, two elbows and the 2nd and 3rd metacarpo-phalangians of left hand. There was no node.

The X-ray of the hands, the front feet and the left knee objectified a stern destructive gouty arthropathy (Figure 2). At the right knee, they showed a stern septic synovitis with complete disappearance of the joint spacing, important diffuse demineralization and erosion of the external tibial tray (Figure 3). The MRI of the right knee confirmed arthritis with articular spring (Figure 4).

Inflammatory syndrome was important (ESR $=50 \mathrm{~mm}$ in the 1 st hour and CRP $=28 \mathrm{mg} / \mathrm{l}), 17,510$ white leucocytes per $\mathrm{mm}^{3}$ with neutrophile predominance $\left(14,080 \mathrm{PNN} / \mathrm{mm}^{3}\right)$. Uricemia was at $84 \mathrm{mg} / \mathrm{l}$, creatininemia at $10.4 \mathrm{mg} / \mathrm{l}$. The glycaemia, the blood ionogram, transaminases, lipid evaluation, HIV serology as well as the B and $C$ hepatic serologies were normal. The haemocultures and the urines culture were negative. The analysis of the synovial liquid objectified 26,000 white corpuscles, in PNN predominance (100\%). The culture identifies a negative gram bacillus. It was a Morganella morganii, multi resistant, sensitive at the Imipeneme and to the only aminosides. In spite of the treatment associating allopurinol, colchicine [2] and a bi-antibiotherapy by gentamicin, third generation of céphalosporin (the imipeneme not being available), evolution was lethal, in a picture of multi-visceral failing.

\section{Discussion}

In sub-Saharan Africa, the septic arthritis is the second reason of arthritis and an emergency in Rheumatology [6] [7]. Among the factors of risk identified of septic arthritis, the existence of a preexisting arthropathy is one of it [8]. However, the drop although being the first inflammatory arthropathy reason in hospitable environment is not described as factor associated to the intervening of an infectious arthritis [6] [9] [10]. If this association

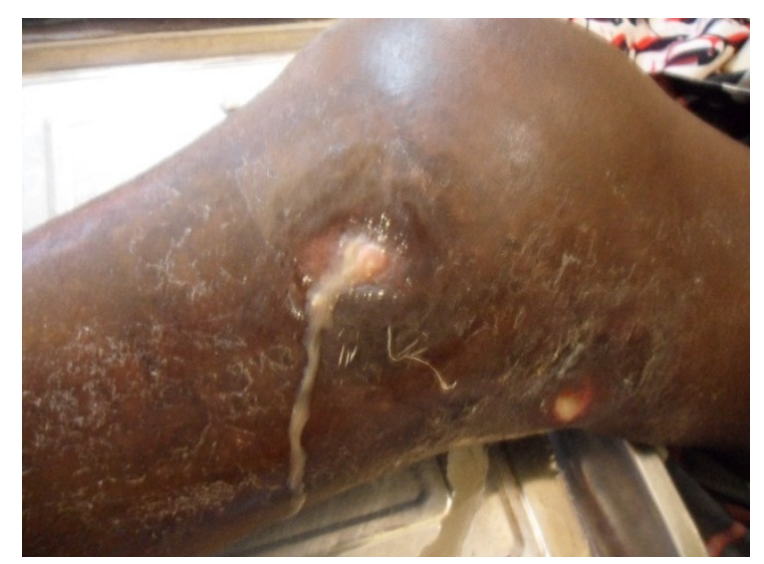

Figure 1. Inflammatory swollen of right knee, letting spring the pus, through two cutaneous fistulas. 


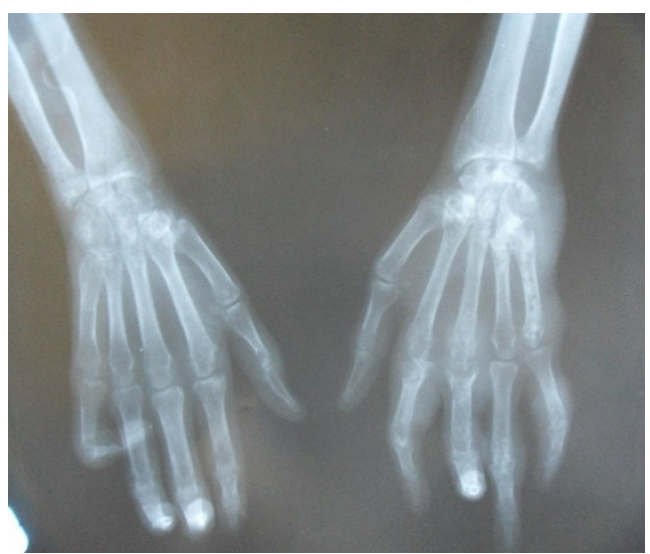

Figure 2. X-ray of two face's hands and wrists giving prominence to a severe destructive gouty arthropathy and tophus.

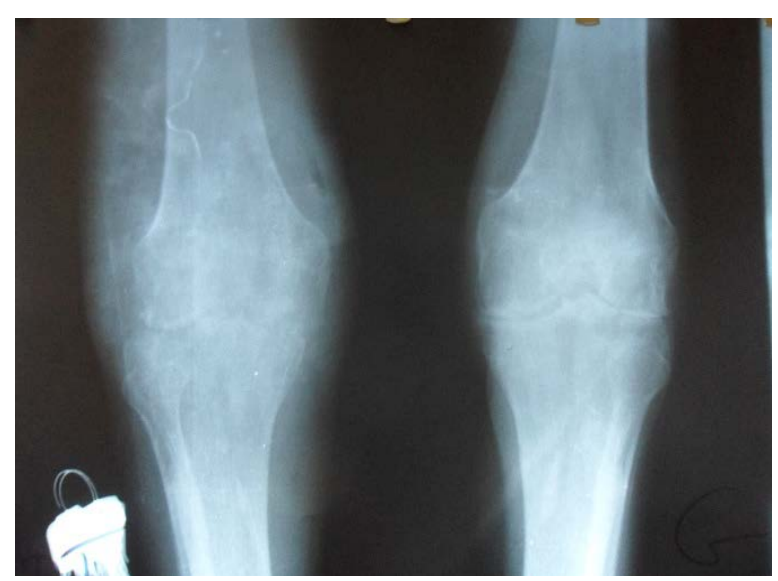

Figure 3. X-ray of the two knees giving prominence to a destructive arthritis.

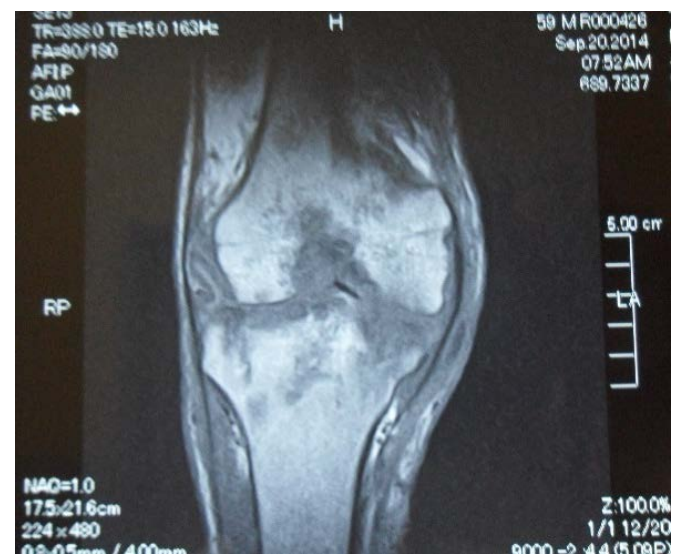

Figure 4. MRI of the right knee giving prominence to tibial trays and femoral condyles destructive arthritis.

appears unaccustomed, it seems not to be exceptional [11]. Yu H.K. et al. [12] as well as Weng C.T. et al. [13] respectively reported retrospective set of 30 and 14 cases of concomitant septic arthritis of a gout crisis in ten years. For Yu H.K. et al. [12], there could be genetic factors related to the race intervening in the susceptibility 
to develop a septic arthritis associated to a gouty crisis.

The joint bacterial colonization occurs in general at a chronic gouty patient presenting an oligo or polyarticular gout, tophaced, as in our case. There sometimes exists a factor encouraging the expected arrival of an infectious complication, notably diabetes mellitus, corticotherapy, transplantation, prothetic surgery and plastic surgery of the tophus. In our case, it seems that the debilitating associated factor is alcohol, no other factor having been found [12]-[14]. It has been reported that the crisis of gout is secondary to the influx of polynuclear and to the lactic acidic production, generated by the joint super-infection, dragging a decrease of the intra articular $\mathrm{PH}$, encouraging the precipitation of sodium urate crystals [15]. The usual clinical presentation in case of sepsis is an acute monoarthritis of brutal installation to a chronic gouty patient more often oligo or polyarticular and tophaced. The fever more often appears, but in $30 \%$ of the cases it is absent, that must not make exclude the diagnosis. In general, the joint is the seat of an important inflammation associating swelling, redness, shininess and stiffness. The knee is the most often concerned joint, $80 \%$ in the set of H.K. Yu et al. [12]; 57,1\% related by C.T. Weng [13]. In this context the analysis of the joint fluid is fundamental, because it permits the certitude diagnosis. This one reveals the association of microbial agent and presence of sodium urate crystals [14]-[16]. Staphylococcus is the most often involved in the published sets. This predominance is especially explained by a predominant cutaneous entry door (an ulceration of tophus). The negative gram bacillus are less frequent and exceptionally Morganella morganii [17]. It is a bacterium saprophyte of gastro intestinal flora, family of the enterobacteria and arthritis is rarely reported. The bacterial joint colonization by this germ is often encouraged by the existence a medical context debilitating such as the diabetes mellitus, the prolonged corticotherapy, alcoholism (as in our set), neoplasia or rheumatoid arthritis [18].

\section{Conclusion}

The concomitant joint septic graft of a gout crisis is exceptional and of difficult diagnosis. It often complicates the chronic oligo or polyarticular tophaced gout, to a patient debilitated by a general illness or local articular disability. The diagnosis of this association is difficult and can be delayed because of the absence of infectious syndrome. In this context, the analysis of the joint fluid has all its importance to the certitude diagnosis and to bring bacterial proof.

\section{References}

[1] Roddy, E. and Doherty, M. (2010) Epidemiology of Gout. Arthritis Research \& Therapy, 12, 223-234. http://dx.doi.org/10.1186/ar3199

[2] Bileckot, R., Ntsiba, H., Mbongo, J.A., Sigamong, E.V., Masson, C. and Brégeon, C. (1991) Epidemiological and Clinical Aspects of Gout in Equatorial Africa. Apropos of 60 Cases Followed in the Department of Rheumatology of the Teaching Hospital Center in Brazzaville. Revue du Rhumatisme et des Maladies Ostéoarticulaires, 58, 863-867.

[3] Mijiyawa, M. (1995) Gout in Patients Attending the Rheumatology Unit of Lomé Hospital. Rheumatology, 34, 843846. http://dx.doi.org/10.1093/rheumatology/34.9.843

[4] Tikly, M., Bellingan, A., Lincoln, D. and Russell, A. (1998) Risk Factors for Gout: A Hospital-Based Study in Urban Black South Africans. Revue du Rhumatisme, 65, 225-231.

[5] Ntsiba, H. and Bazebissa, R. (2000) Goutte du genou et arthrite septique associée. Médecine et Maladies Infectieuses, 30, 724-725. http://dx.doi.org/10.1016/S0399-077X(01)80008-1

[6] Bilekot, R., Ntsiba, H., Okongo, D., Ognami, J.B., et al. (1994) Arthritis in Black Africa: A Review of Four Hundred Seventy-Three Cases in black Africa. Revue du Rhumatisme, 61, 245-250.

[7] Ntsiba, H., Makosso, E., Ngandeu-Singwe, M. and Yala, F. (2006) Les arthrites septiques en zone tropicale. A propos de 176 cas observés à Brazzaville. Mali Médical, 21, 49-54.

[8] Dubost, J.J., Soubrier, M. and Sauvezie, B. (2000) Arthrite septique à pyogène de l'adulte. Revue du Rhumatisme, 67, 17-27. http://dx.doi.org/10.1016/S1169-8330(00)80043-5

[9] Zenze, J.R., Belembaogo, E., Magne, C., Sanou, A.S., et al. (2001) Panorama des arthropathies inflammatoires à Libreville : analyse d'une série de 57 observations. Médecine d'Afrique Noire, 48, 399-402.

[10] Oniankitan, O., Bagayogo, Y., Fianyo, E., Koffi-Tessio, V., et al. (2011) Arthrites infectieuses en consultation rhumatologique à Lomé (Togo). Médecine Tropicale, 71, 61-62.

[11] Shah, K., Spear, J., Nathanson, L.A., McCauley, J. and Edlow, J.A. (2007) Does the Presence of Cristal Arthritis Rule out Septic Arthritis? The Journal of Emergency Medicine, 32, 23-26. http://dx.doi.org/10.1016/j.jemermed.2006.07.019 
[12] Yu, K.H., Luo, S.F., Liou, L.B., Wu, J.J., et al. (2003) Concomitant Septic and Gouty Arthritis: An Analysis of 30 Cases. Rheumatology, 42, 1062-1066. http://dx.doi.org/10.1093/rheumatology/keg297

[13] Weng, C.T., Lui, M.F., Lin, L.H., Weng, M.Y., et al. (2009) Rare Coexistence of Gouty and Septic Arthritis: A Report of 14 Cases. Clinical and Experimental Rheumatology, 27, 902-906.

[14] Paniker, V.N., Turner, J.K. and Chehade, M.J. (2014) Concomitant Septic Arthritis and Tophaceous Gout of the Knee Managed with Intermittent Closed Joint Irrigation Combined with Negative Pressure Therapy: A Case Study and Literature Review. The Open Orthopaedics Journal, 8, 482-787. http://dx.doi.org/10.2174/1874325001408010482

[15] Tejera, B., Riveros, A., Martinez-Morillo, M. and Canellas, J. (2014) Septic Arthritis Associated to Gout and Pseudogout: The Importance of Arthrocenthesis. Reumatología Clínica, 10, 61-62. http://dx.doi.org/10.1016/j.reumae.2013.01.010

[16] Baker, J.F. and Stonecypher, M. (2009) Coexistence of Oligo-Articular Gout and Mycobacterium kansasii Joint and Bursal Infection in a Patient with an Orthotopic Heart Transplant. Clinical and Experimental Rheumatology, 27, 843-845.

[17] Gautam, V., Gupta, V. and Joshi, R.M. (2003) Morganella morganii-Associated Arthritis in a Diabetic Patient. Journal of Clinical Microbiology, 41, 3451. http://dx.doi.org/10.1128/JCM.41.7.3451.2003

[18] Koyuncu, S. and Ozan, F. (2012) Morganella morganii Osteomyelitis Complicated by Secondary Septic Knee Arthritis: A Case Report. Acta Orthopaedica et Traumatologica Turcica 46, 464-467. http://dx.doi.org/10.3944/AOTT.2012.2847

\section{Abbreviaitions}

ESR: Erythrocyte Sedimentation Rate

CRP: C-Reactive Protein

PNN: Neutrophil Polynuclear

HIV: Human Immunodeficiency Virus 